\title{
A study of prevalence of asymptomatic bacteriuria in pregnant women from rural areas attending to Obstetric Department in Akash Hospital, Karnataka, India
}

\author{
Rohini N. S. ${ }^{*}$, Ravishankar S. N. ${ }^{2}$, Kala K. ${ }^{3}$, Rakshith N. R. ${ }^{4}$
}

\begin{abstract}
${ }^{1}$ Associate professor, Department of Obstetrics and Gynecology, ${ }^{2}$ Professor and HOD, Department of Internal Medicine, ${ }^{3}$ Professor and HOD, Department of Obstetrics and Gynecology, Akash Institute of Medical Sciences and Research Centre, Karnataka, India

${ }^{4}$ UG medical student, JSS Medical College, Karnataka, India
\end{abstract}

Received: 10 June 2019

Accepted: 17 June 2019

\section{*Correspondence:}

Dr. Rohini N. S.,

E-mail: dr.rohini.ns@gmail.com

Copyright: () the author(s), publisher and licensee Medip Academy. This is an open-access article distributed under the terms of the Creative Commons Attribution Non-Commercial License, which permits unrestricted non-commercial use, distribution, and reproduction in any medium, provided the original work is properly cited.

\begin{abstract}
Background: Asymptomatic bacteriuria (ASB) in pregnancy is a significant risk factor for developing upper urinary tract infection and pyelonephritis which is associated with significant maternal and fetal risks. The aim of this study was to know the prevalence of asymptomatic bacteriuria in pregnancy, to identify the organisms and their antibiotic susceptibility patterns and to formulate a single or combined rapid screening method as an acceptable alternative to urine culture.

Methods: A total of 375 pregnant women aged between 18 to 45 years were included in this study. Clean catch midstream urine samples were collected. Screening tests done were gram staining of uncentrifuged urine, pus cell count, nitrite test and leukocyte esterase test. Identification of pathogens and antibiotic sensitivity tests were performed as per standard urine culture and sensitivity methods.

Results: Out of the 375 pregnant women, $31(8.4 \%)$ had significant bacteriuria. High percentage of women with ASB were primigravidas $(51.38 \%)$ and in $2^{\text {nd }}$ trimester $(43.86 \%)$. The most common organism isolated was E. coli $(56.14 \%)$. In screening tests, gram staining of uncentrifuged urine had a sensitivity of $85.71 \%$. Sensitivity of $71.42 \%$ was found in Nitrite and leucocyte esterase tests. However, the combination of these two tests, with either test positive, showed sensitivity and negative predictive value of $90.47 \%$ and $99.09 \%$ respectively.

Conclusions: Early detection and treatment of ASB in pregnancy can prevent complications. ASB can be identified by simple and combined rapid screening methods and urine culture along with antibiogram. Therefore, screening and treatment of ASB may be incorporated as routine antenatal care for safe motherhood and healthy newborn.
\end{abstract}

Keywords: Asymptomatic bacteriuria, Pregnancy, Screening tests

\section{INTRODUCTION}

Asymptomatic bacteriuria is the presence of more than 100000 colonies of a single bacterial species per milliliter of urine, cultured from midstream sample, in the absence of symptoms like dysuria, frequency, urgency and loin pain. ${ }^{1-5}$ One of the major risk factors in developing Urinary Tract Infection (UTI) in pregnancy is asymptomatic bacteriuria (ASB). ${ }^{6}$ There is urethral dilatation in $90 \%$ of pregnant women which starts at 
about $6^{\text {th }}$ week and peaks at about 22 to 24 weeks and remains so till delivery. Bladder volume increases, bladder and urethral tone decreases. These contribute to increased urinary stasis and ureterovesical reflux. This accounts for $70 \%$ of asymptomatic UTI among unscreened pregnant women. ${ }^{5}$ Pyelonephritis develops in 20 to $40 \%$ of pregnant women with untreated asymptomatic bacteriuria. Untreated bacteriuria can have serious implications such as premature birth, low birth weight, perinatal death in foetus and preeclampsia, anaemia, amnionitis and endometritis in the mother. ${ }^{7,8}$ During pregnancy, $40-80 \%$ complications caused by acute pyelonephritis could be prevented by treating asymptomatic bacteriuria. All these factors justify screening pregnant women for ASB and treating them accordingly. The American College of Obstetrics and Gynaecology advocates routine screening for bacteriuria with a urine culture at the first prenatal visit and during the third trimester.

The standard reference test for bacteriuria is urine culture and sensitivity, which is expensive, time consuming, laborious and requires a laboratory and qualified staff. This may not be available in many areas, especially where preterm delivery, low birth weight and other complications of asymptomatic bacteriuria are associated with higher morbidity and mortality. Hence the best alternative screening test which can be used remains to be determined $^{6}$. Thus the aim of the present study was to determine the prevalence of asymptomatic bacteriuria in pregnant women, the common pathogens isolated with their antibiotic sensitivity pattern, to compare the sensitivity of different screening methods (Gram-staining, nitrite test, leukocyte esterase test, pus cell count) and to formulate a single or combined rapid screening method, which can provide an acceptable alternative to screen all asymptomatic patients with urine culture.

\section{METHODS}

This was a cross-sectional study conducted at Department of Obstetrics and Gynecology, Akash Institute of Medical Sciences and Research Center, Devanahalli, Karnataka, India. A total of 375 pregnant women aged between 18 to 45 years who attended the Obstetrics and Gynecology department were included in this study. Any gestational age, singleton pregnancy, no history of rupture of membranes, no history of preterm labor in previous pregnancies was included in the study.

Pregnant women with fever, symptoms of urinary tract infections such as hesitancy, dysuria, urgency, frequent voiding, incomplete voiding and incontinence, pregnancy induced hypertension, diabetes, sickle cell disease, history of antibiotic therapy in previous 2 weeks, known congenital anomalies of urinary tract were excluded from the study. Duration of the study was 1 year, from October-2017 to October-2018. The study was approved by the Institutional Ethics Committee and Informed consent was obtained from the study subjects. Mid- stream clean catch urine samples were collected from all the pregnant women and processed. The study and data collection were carried out.

\section{Specimen collection}

Thorough instructions were given to every patient and asked to collect clean catch midstream urine of about 20 $\mathrm{mL}$ in a sterile universal container and the urine sample was transported to the Microbiology laboratory within one hour. In case of delay, the sample was refrigerated at $4^{\circ} \mathrm{C}$ for as long as 24 hours ${ }^{9}$. The urine samples were observed macroscopically for its color, turbidity and deposits and the findings were recorded and then subjected to different tests as follows:

\section{Screening procedures}

\section{Gram stain of uncentrifuged urine}

A drop of urine was smeared on slide, air dried, fixed, stained and was examined under oil-immersion. Presence of at least one organism per oil immersion field (examining 20 fields) was considered as significant bacteriuria.

\section{Pus cell count of the uncentrifuged urine}

Presence of pus cells in urine is the hallmark of inflammation and pus cells were counted using a Neubauer's counting chamber. The presence of $>8$ $\mathrm{PMNs} / \mathrm{mm}^{3}$ was considered significant bacteriuria. A 1:1 dilution of $0.1 \mathrm{ml}$ of urine and WBC diluting fluid (Turck's fluid) was taken and charged on to the Neubauer's counting chambers and the pus cells were counted at all the 9 squares under the microscope using low (10x) objective and calculated by using the formula.

Pus cell count $=$ Number of pus cells $\times$ depth factor $\times$ dilution factor $\div$ Area covered

\section{Nitrate reductase (Griess) test and leucocyte esterase test}

A dipstick method was used for these tests (COMBUR 10 Boehringer Mannheim and Co.) which determines 10 different parameters. Most of the urinary tract pathogens produce nitrate reducing enzymes that reduce nitrate to nitrites, which react with an amine impregnated on the dipstick pad to form a diazonium compound giving rise to a pink colour within 60 seconds.

Leucocyte esterase is an enzyme produced by inflammatory cells. It reacts with the chloro acetate stain impregnated in a dipstick pad resulting in an iodoxyl moiety that is oxidized by room air and produces a color change to violet in 1 to 2 minutes.

The strip was dipped in the well-mixed uncentrifuged urine for no longer than a second. After withdrawing the strip, excess urine along the rim of vessel was wiped. 
After 1 minute the colour change in the strip was compared with the color scales provided with the kit. Pink color produced was considered as nitrate positive and a violet colour was considered as leucocyte esterase positive. Any colour change appearing only along the edges of the test patches or developing after more than 2 minutes were not considered significant.

\section{Quantitative bacteriology}

The urine was cultured on CLED agar. A loopful of well mixed uncentrifuged urine was streaked on to the surface of culture plates. Incubation was done aerobically at $37^{\circ} \mathrm{C}$ for 24 to 48 hours. After counting the colonies, the number of CFUs was multiplied by 100 to determine the numbers of microorganisms per milliliter in the original specimen. Count with $105 \mathrm{CFU} / \mathrm{mL}$ was considered as significant. Mixed growth of 2 or more organism was considered as contamination. The isolates were further identified on the basis of colonial morphology, cultural characteristics, Gram's staining and a battery of biochemical reactions. Significant bacterial isolates were identified by standard procedures and were subjected to antibiotic susceptibility by Kirby Bauer's disc diffusion method. ${ }^{10}$

\section{Statistical analysis}

The results of prevalence of asymptomatic bacteriuria, organisms isolated, their antibiograms and their distribution among pregnant females are expressed as percentages. Microsoft excel was used for the interpretation of these results. For comparisons of screening tests - sensitivity, specificity, positive predictive value and negative predictive values SPSS-7.5 version software was used.

\section{RESULTS}

Table 1: Baseline characteristics of study subjects

\begin{tabular}{|lll|}
\hline $\begin{array}{l}\text { Characteristics } \\
\text { Age (in years) }\end{array}$ & $\begin{array}{l}\text { No. of cases } \\
(\mathbf{n = 3 7 5})\end{array}$ & $\begin{array}{l}\text { No. of cases with } \\
\text { ASB } \%(\mathbf{n}=\mathbf{3 1})\end{array}$ \\
\hline $18-25$ & 72 & $6(20.05)$ \\
\hline $26-30$ & 231 & $19(60.90)$ \\
\hline $31-35$ & 48 & $4(13.29)$ \\
\hline $36-40$ & 18 & $2(5.76)$ \\
\hline $41-45$ & 6 & $0(0)$ \\
\hline Parity & & \\
\hline Primigravida & 181 & $16(51.38)$ \\
\hline Gravida2 & 139 & $9(29.57)$ \\
\hline Gravida3 & 44 & $6(19.05)$ \\
\hline Gravida4+ & 11 & $0(0)$ \\
\hline Gestational Age & & \\
\hline $1^{\text {st }}$ Trimester & 153 & $7(22.81)$ \\
\hline $2^{\text {nd }}$ Trimester & 165 & $14(43.86)$ \\
\hline $3^{\text {rd }}$ Trimester & 57 & $10(33.33)$ \\
\hline
\end{tabular}

Out of the total 375 pregnant women included in this study, $31(8.3 \%)$ patients were identified by culture to have significant bacteriuria of which $61.9 \%$ of them were between 26 to 30 years. High percentage of asymptomatic bacteriuria was seen in $2^{\text {nd }}$ trimester $(42.86 \%)$ and in primigravidas $(51.38 \%)$. The predominant causative organisms were Gram negative (78.95\%) than gram positive organisms $(21.05 \%)$. E. coli $(56.14 \%)$ was the most common organism which was isolated (Figure 1, Figure 2, Table 2).

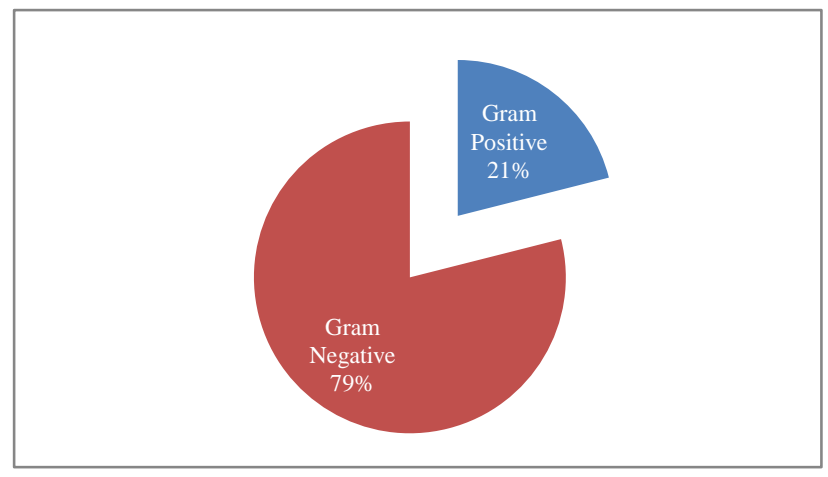

Figure 1: Percentage of gram positive and gram negative organisms causing ASB.

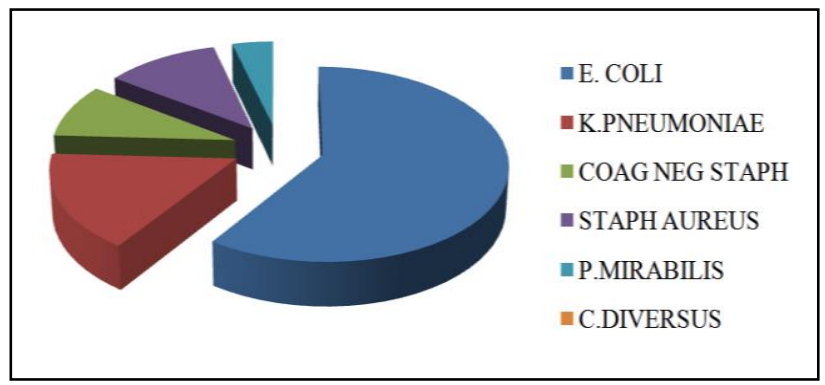

Figure 2: Relative percentage of organisms causing ASB $(n=31)$

Table 2: Organisms causing ASB

\begin{tabular}{|lll|}
\hline Organisms & No. of organisms & $\%(n=31)$ \\
\hline E. coli & 17 & 56.14 \\
\hline K. pneumoniae & 5 & 15.3 \\
\hline $\begin{array}{l}\text { Coagulase negative } \\
\text { Staph }\end{array}$ & 3 & 8.52 \\
\hline Staph aureus & 3 & 10.52 \\
\hline P. mirabilis & 1 & 3.76 \\
\hline C. diversus & 2 & 5.76 \\
\hline
\end{tabular}

The antibiograms revealed that $95.23 \%$ of isolates were sensitive to ciprofloxacin, followed by cefotaxime $(80.95 \%)$, ceftriaxone $(76.19 \%)$ and gentamicin $(66.67 \%)$. Among the antibiotics ciprofloxacin, cefotaxime and ceftriaxone were most effective $(100 \%$ sensitive against $S$. aureus, $P$. mirabilis and $C$. diversus) while amoxicillin and cephalexin were the least effective with only $23.80 \%$ and $33.33 \%$ sensitivity rates. As 
ciprofloxacin is contraindicated in pregnancy, the patients were treated with either cefotaxime or ceftriaxone.

Table 3: Distribution of statistical values for various screening subjects

\begin{tabular}{|llllll|}
\hline Test & True + & True & False + & False - & Total no. of cases \\
\hline Gram stain & 27 & 339 & 4 & 5 & 375 \\
\hline Pus cell count & 13 & 327 & 17 & 18 & 375 \\
\hline Nitrite test & 22 & 342 & 2 & 9 & 375 \\
\hline Leucocyteesterase test & 22 & 316 & 27 & 10 & 375 \\
\hline $\begin{array}{l}\text { Combined nitrite and } \\
\text { leucocyte esterase }\end{array}$ & 16 & 344 & 0 & 15 & 375 \\
\hline $\begin{array}{l}\text { Either nitrite test or } \\
\text { leucocyte esterase test }\end{array}$ & 28 & 330 & 14 & 3 & 375 \\
\hline
\end{tabular}

Table 4: Distribution of statistical values for various screening tests

\begin{tabular}{|lllll|}
\hline Test & Sensitivity (\%) & Specificity (\%) & Positive predictive value & Negative predictive value \\
\hline Gram stain & 85.71 & 98.68 & 85.71 & 98.68 \\
\hline Pus cell count & 42.85 & 95.19 & 45 & 94.78 \\
\hline Nitrite test & 71.42 & 99.56 & 93.75 & 97.43 \\
\hline $\begin{array}{l}\text { Leucocyteesterase test } \\
\text { Combined nitrite and } \\
\text { leucocyte esterase test }\end{array}$ & 52.42 & 92.13 & 45.45 & 97.9 \\
\hline $\begin{array}{l}\text { Either nitrite test or } \\
\text { leucocyte esterase test }\end{array}$ & 90.47 & 100 & 100 & 95.71 \\
\hline
\end{tabular}

Among the screening tests, the sensitivity of gram staining of uncentrifuged urine was $85.71 \%$ and negative predictive value was $98.68 \%$. Though Nitrite and leukocyte esterase tests alone showed sensitivity of $71.42 \%$, the combination of these two tests, either tests positive, had sensitivity and negative predictive value of $90.47 \%$ and $99.09 \%$ respectively (Table 3 and Table 4)

\section{DISCUSSION}

Asymptomatic bacteriuria of pregnancy requires special attention, because of lack of symptoms and its adverse consequences in pregnancy ${ }^{11,12}$. A cost evaluation study reported that screening for pyelonephritis is appropriate when the prevalence of ASB is greater than $2 \%$. In the present study, the prevalence of asymptomatic bacteriuria was $8.3 \%(31 / 375)$ which was almost similar to a study done in Iran $(8.9 \%)^{14}$ and Raichur $(9 \%)^{15}$. But studies done in Nepal ${ }^{16}$, Lucknow ${ }^{17}$ and Srilanka ${ }^{18}$ showed higher and lower prevalence rates of $26 \%, 16.9 \%$ and $3.6 \%$ respectively.

In our study, the prevalence was seen to be higher in women belonging to 26 to 30 years of age group $(61.90 \%)$, in primigravidas $(51.38 \%)$ and during second trimester $(43.86 \%)$. Similar findings were reported in other studies done in Raichur ${ }^{15}$ and Belgaum ${ }^{12}$ where $52 \%$ and $57 \%$ of cases belonged to 26 to 35 years of age, $56 \%$ and $59 \%$ were primigravidas and $44.04 \%$ and
$54.54 \%$ of cases were in second trimester respectively. But a study done by Hassan ${ }^{19}$ showed higher prevalence of asymptomatic bacteriuria $(61.77 \%)$ in the third trimester of pregnancy, while a study done in Ghana ${ }^{20}$ showed $36.80 \%$ of cases within $30-34$ years age group.

In our study, Gram negative organisms were predominant $(78.95 \%)$ than Gram positive $(21.05 \%)$ and E. coli $(56.14 \%)$ was the commonest followed by $K$. Pneumoniae (15.3\%). Most of the other studies also have reported $E$. coli as the commonest pathogen but with higher isolation rates than our study $(72.72 \%, 77.77 \%$, $70.8 \%$, and $67 \%$ ). Studies done in Hassan and Iran showed almost similar isolation rate of E. coli $(51.61 \%$ and $58.96 \%$ ) as our study. ${ }^{14,19}$ However, in one study done in Nigeria $S$. aureus was the most common pathogen (72\%) and E. coli was the least common (2\%). ${ }^{21}$

In most cases culture sensitivity to Ciprofloxacin, Cephalexin, Cefotaxime and Ceftriaxone was found. Different studies have shown nitrofurantoin/fosfomycin as drug of choice during pregnancy. However, we found that the sensitivities to amoxicillin-clavulanic acid (52.38\%), nitrofurantoin and cotrimoxazole $(47.61 \%)$, nalidixic acid $(42.85 \%)$, cephalexin $(33.33 \%)$, and amoxicillin $(23.80 \%)$ which are used as drugs of choice in treating asymptomatic bacteriuria were comparatively lower. A study done by Oli et al, showed similar antibiotic sensitivities with regard to Ceftriaxone 
(75.38\%), Gentamicin (60\%), Amoxicillin-Clavulanic acid $(55.38 \%)$ and Cephalexin $(29.23 \%)$, but was in contrast to our study when compared with Amoxicillin $(44.62 \%)$, Nitrofurantoin $(35.38 \%)$, Cotrimoxazole $(33.84 \%)$ and Nalidixic acid $(32.31 \%) .^{22}$

An ideal screening test should have a high negative predictive value so that it will identify all the positive cases. Also it should be simple, rapid and accurate. Four screening tests, namely, gram's stain of uncentrifuged urine, pus cell count, nitrite test and leukocyte esterase tests were used in our study. Gram stain of uncentrifuged urine was the most useful single test in our study and had a sensitivity of $85.7 \%$ and negative predictive value (NPV) of $98.68 \%$. Similar sensitivity to gram stain was seen in the study done by Gayathree et al, and Jayalakshmi et al. ${ }^{7,19}$

In our study, neither nitrite test nor the leukocyte esterase test was acceptable by itself as a screening test (sensitivities of both being $71.42 \%$ ). However, a combination of these two tests was analyzed as a single dipstick method, so that a convenient and easy office method can be made available. When both the tests were positive, positive cases of asymptomatic bacteriuria were correctly identified in $100 \%$ of the cases. The negative predictive value of a normal test (i.e. negative nitrite and leukocyte esterase) was $95.81 \%$.

\section{CONCLUSION}

The main aim of our study was to estimate the prevalence of asymptomatic bacteriuria in pregnant women, irrespective of their age, parity and period of gestation. Also, the other objectives were to identify the most common pathogens involved and their susceptibility pattern and to compare the sensitivity and specificity of various screening methods so that a simple, rapid and accurate method can be formulated instead of the time consuming, costly and laborious urine culture test.

In the present study, a total of 375 pregnant women were screened for the presence of asymptomatic bacteriuria. The prevalence of ASB in our study was $8.3 \%$ and $60.9 \%$ of them were between 26 to 30 years. Most of the patients were primigravida $(51.38 \%)$ and a higher incidence of ASB was seen in second trimester $(43.86 \%)$. E. coli was the most predominant organism $(56.14 \%)$ and antibiograms revealed that ciprofloxacin, cefotaxime and ceftriaxone were the most effective antibiotics. The most useful test was gram staining of uncentrifuged urine. Though the sensitivity of nitrite test and leukocyte esterase test alone was found less at $71.42 \%$, the combination of these two colorimetric tests used as a dipstick with either test positive, had a sensitivity and negative predictive value of $90.47 \%$ and $99.09 \%$ respectively. Therefore, screening and treatment of ASB may be incorporated as routine antenatal care for safe motherhood and healthy newborn.

\section{ACKNOWLEDGMENTS}

Authors would like to thank the authorities of Akash Institute of Medical Sciences and Research Centre, Devanahalli, Bengaluru, Karnataka, India for thier support during study.

Funding: No funding sources

Conflict of interest: None declared

Ethical approval: The study was approved by the Institutional Ethics Committee

\section{REFERENCES}

1. Cram LF, Zapata MI, Toy EC, Baker B. Genitourinary infections and their association with preterm labor. Am Family Physician. 2002;65:241-8.

2. Girishbabu RJ, Srikrishna R, Ramesh ST. Asymptomatic bacteriuria in pregnancy. Int $\mathrm{J}$ Biol Med Res. 2011;2(3):740-2.

3. Nicole LE. Screening for asymptomatic bacteriuria in pregnancy. In: Nicole LE, eds. Canadian Guide to Clinical Preventive Health Care. Ottawa: Health Canada. 1994:100-106.

4. Gilstrap LC, Ramin SM. Urinary tract infections during pregnancy. Obstet Gynaecol Clin N Am. 2001; 28(3):581-91.

5. Lavanya SV, Jogalakshmi D Asymptomatic bacteriuria in antenatal women. Indian $\mathrm{J}$ Med Micribiol. 2002;20:105-6.

6. DeIzell JE, Lefevre ML. Urinary tract infections during pregnancy. Am Fam Physician. 2000;61(3):713-21.

7. Jayalaxmi J, Jayaram VS. Evaluation of various screening tests to detect asymptomatic bacteriuria in pregnant women: IJPM. 2008;51(3):379-81.

8. Bandyopadhyay S, Thakur JS, Ray P, Kumar R. High prevalence of bacteriuria in pregnancy and its screening methods in North India. J Indian Med Assoc. 2005;103(5):9.

9. Koneman EW, Allen SD, Janda WM, Schrechenberger PC, Winn WC. Introduction to microbiology: Part II: guidelines for the collection, transport, processing, analysis and reporting of cultures from specific specimen sources. In: Koneman EW, Allen SD, Janda WM, Schrechenberger PC, Winn WC, eds. Color Atlas And Textbook Of Diagnostic Microbiology. 5th ed. Philadelphia: Lippincott. 1997:136-142.

10. Carman RH. Haematology. In: Carman RH, eds. Handbook of Medical Laboratory Technology. $2^{\text {nd }}$ ed. New Delhi: Christian Medical Association of India. 2004:76-156.

11. Wayne PA. Performance standards for antimicrobial susceptibility testing. In: Wayne PA, eds. Clinical and Laboratory Standards Institute. Nineteenth informational supplement. USA: CLSI; 2009:M100S19.

12. Kerure RD, Umashanker. Prevalence of asymptomatic bacteriuria among pregnant women in 
a tertiary care hospital. Int J Sci Res Publ. 2013;3(11):1-4.

13. Rouse DJ, Andrews WW, Goldenberg RL, Owen J. Screening and treatment of asymptomatic bacteriuria of pregnancy to prevent pyelonephritis: a costeffectiveness and cost-beneficial analysis. Obstet Gynaecol. 1995;86:119-23.

14. Enayat K, Fariba F, Bahram N. Asymptomatic bacteriuria among pregnant women referred to outpatient clinics in Sanandaj, Iran. Int Braz J Urol. 2008;34(6):699-707.

15. Kerure SB, Surpur R, Sagarad SS, Hegadi S. Asymptomatic bacteriuria among pregnant women. Int J Reprod Contracept Obstet Gynaecol. 2013;2:213-6.

16. Neupane MS, Dhakal KS, Neupane HC, Adhikari S, Aryal B. Asymptomatic bacteriuria among pregnant women attending the outpatient clinic of Chitwan medical college teaching hospital, Chitwan, Nepal. Int Res J Pharm. 2012;3(11):78-80.

17. Jain V, Das V, Agarwal A, Pandey A. Asymptomatic bacteriuria and obstetric outcome following treatment in early versus late pregnancy in north Indian women. Indian J Med Res. 2013;137:753-8.

18. Jennifer P, Cyril R, Piyumi P, Nimesha G, Renuka J. Asymptomatic bacteriuria in pregnancy: prevalence, risk factors and causative organisms. Sri Lankan J Infect Dis. 2012;1(2):42-6.
19. Gayathree L, Shetty S, Deshpande SR, Venkatesha DT. Screening for asymptomatic bacteriuria in pregnancy: an evaluation of various screening tests at the Hassan district hospital, India. J Clin Diagn Res. 2010;4(4):2702-6.

20. Obirikorang C, Quaye L, Bio FY, Amidu N, Acheampong, Addo K. Asymptomatic bacteriuria among pregnant women attending ante-natal clinic at the university hospital, Kumasi, Ghana. J Med Biomed Sci. 2012;1(1):38-44.

21. Ajayi AB, Nwabuisi C, Aboyeji AP, Ajayi NS, Fowotade A, Fakeye OO. Asymptomatic bacteriuria in antenatal patients in Ilorin, Nigeria. Oman Med J. 2012;27(1):31-5.

22. Oli AN, Okafor CI, Ibezim EC, Akujiobi CN, Onwunzo MC. The Prevalence and bacteriology of asymptomatic bacteriuria among antenatal patients in Nnamdi Azikiwe University teaching hospital Nnewi; South Eastern Nigeria. Nigerian J Clin Practice. 2010;13(4):409-12.

Cite this article as: Rohini NS, Ravishankar SN, Kala K, Rakshith NR. A study of prevalence of asymptomatic bacteriuria in pregnant women from rural areas attending to Obstetric Department in Akash Hospital, Karnataka, India. Int J Reprod Contracept Obstet Gynecol 2019;8:2845-50. 